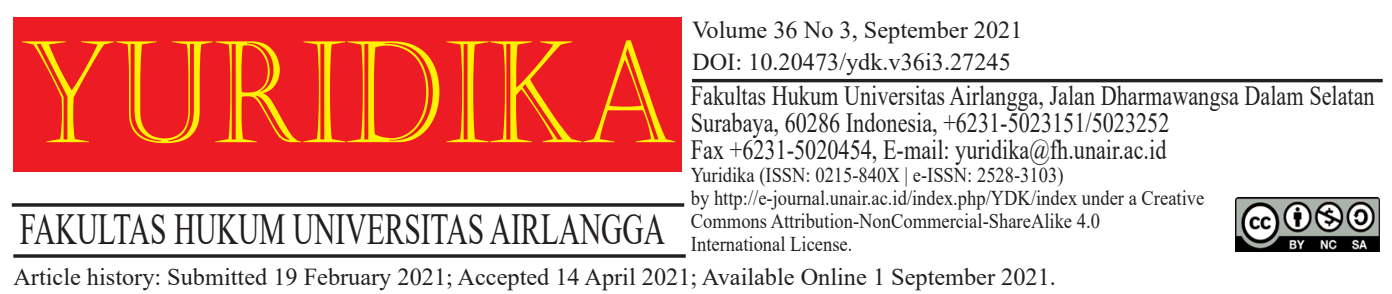

\title{
Ratio Legis on the Right to Language in the Education System in Timor Leste
}

\author{
Antonino Pedro Marsal* and Sukardi ${ }^{* *}$ \\ antoniopedromarsal@gmail.com \\ ${ }^{*}$ University of Dili UNDIL \\ ${ }^{* *}$ Universitas Airlangga
}

\begin{abstract}
East Timor obtained its independence through a referendum conducted by the United Nations (UN). The Constitution of the Democratic Republic of Timor Leste (RDTL) was officially enacted on 20 May 2002. The language clause in Article 13 of the Constitution states that the official languages of East Timor are Tetun and Portuguese. Based on this, the government of East Timor put a policy in place, obligating all levels of the educational system to use only Portuguese in their activities. This policy, however, has faced fierce rejection, especially from private educational institutions, because of its inconsistency with the new reality According to data from the UN, less than 5 per cent of the Timorese population speak Portuguese. In this research, two legal issues emerged. The first is about language as a constitutional right of citizens. The second relates to the use of the Portuguese language in the education system in East Timor and its relation to human rights. To analyse the legal problems, this research utilises qualitative and legal methods. It can be successfully proven that, in the implementation of the language clause in East Timor, the government policy does not consider the legal principle of proportional justice and discriminates against Timorese people who use Tetun and other national languages, which should be encouraged by the nation. The conclusion is that the use of the Portuguese language violates constitutional rights and impedes the quality of education.
\end{abstract}

Keywords: Language; Education System; Constitution; Human Rights.

\section{Introduction}

East Timor gained independence through a referendum organized by the United Nations (UN). On 20 May 2002, the Constitution of the Democratic Republic of East Timor officially entered into force. In the article of the Constitution governing language, Article 13, the official languages of East Timor are listed as Tetun and Portuguese. In the provisions of Article 59, Paragraph C, the state must guarantee 
all citizens who have the ability the opportunity to enter school, participate in the highest level of education, carry out scientific research and artistic creativity. Article 159 states that Indonesian and English are the working languages of East Timor.

We observe in the provisions of Article 59 and Article 159 that it is against government policy to mandate that the education curriculum and all government activities use Portuguese. According to data from the UN in 2006, less than 5 per cent of the population can speak Portuguese. ${ }^{1}$ Many problems arise with students who do not understand the meaning of material given to them by their teachers; instead, they learn it by rote. Similarly, in the legal system, the parties involved in the process may not understand clearly what is conveyed by the judge to the suspect, defendant or convicted person. ${ }^{2}$ Because of these problems, on 15 October 2016, East Timorese president Taur Matan Ruak issued a statement and criticised proceedings being conducted in Portuguese. This hampers the quality of education, violates the constitutional rights of citizens and fails to achieve good governance.

Timor Leste features 36 languages, including Tetun, Mambae, Bekais, Bunak, Dawan, Fataluku, Galole, Habun, Idalaga, Laklei, Kawaimia, Kemak, Lovaia, Makalero Makasae, Tekodede, Wetaresa and Naueti. ${ }^{3}$ Some of these languages are used for communication between one tribe and another; these languages are only used by small groups of people in the area. Meanwhile, the Mambae language is mostly spoken in five districts: Ermera, Manufahi, Aileu, Ainaro and Dili. Forty per cent of the East Timorese population of 1.3 million. Tetun is spoken by 80 per cent of the 13 districts in Timor Leste. Meanwhile, only 5 per cent of the population are Portuguese speakers. They are also an older generation, with an average age of over 55 years old. This data comes from the UNDP in 2006 In my research, by 2019, the percentage of people in East Timor who could speak Portuguese had risen to 6.5 per cent over 13 years. Portuguese has not developed significantly: only an additional

\footnotetext{
${ }^{1}$ Repository Unwira, 'Data Dari Pembngunan PBB (2006)' <https//www.repository 2019/ unwira ac.id> accessed 19 October 2019.

${ }^{2}$ Berita Nasional Timor Leste (TVTL), 'Sebaiknya Di Pengadilan Menggunakan Bahasa Tetun Supaya Para Pihak Mengerti Apa Yang Disampaikan Oleh Para Hakim’ (2015).

${ }^{3}$ Paiseco Luis, 'Lingua Materna En Timor Leste' [1980] Institustu Camoes.[1].
} 
1.5 per cent of the population can speak the language.

Article 59 of the East Timor Constitution says the government is obliged to provide quality education for its citizens. On the other hand, the government policy that the Portuguese language must be used in the education system from primary schools to universities ignores the reality that language is a determining factor in improving education. Because so little of the population speaks Portuguese, this government policy has violated the human right to a good education and runs contrary to the International Covenant on Economic, Social and Cultural Rights.

From 1976 to 1999, East Timor was part of the Republic of Indonesia. In fact, approximately 43 per cent of the population of East Timor can speak the Indonesian language properly and correctly because the Indonesian government was open to the people of East Timor at the time. The younger generation could get scholarships to continue their education at universities in Indonesia.

The regulation of language in the East Timor Constitution, written after the country gained its independence, stipulates in Article 13 that the official languages of the state are Tetun and Portuguese in in Article 159 that the working languages are Indonesian and English. However, the implementation does not use the Indonesian or English of the workers because the majority of the older generation who lived in East Timor during the 24 years it was a province of Indonesia live in Australia, Portugal or Mozambique and cannot speak Indonesian. Therefore, the application of the Portuguese language benefits this group but harms society at large.

The data obtained show that, in the implementation of the national secondary school exam, Tetun is not included as a main language. On the other hand, the Portuguese language is included as one of the important materials in the national curriculum. Tetun is, of course, the original language of the people of East Timor and a cultural representation of their identity.

Based on this background, using Portuguese in the education system in East Timor hinders the quality of education and good governance in terms of public service and the life of the nation. The state has violated the human right to access quality education, in accordance with the mandate of Article 59 of the Constitution. 
Therefore the author raises the following two issues: Is language a constitutional right of citizens? What is the relation between the use of the Portuguese language in the education system and human rights? This study uses a qualitative method to examine the concept of human rights, a statutory approach to analyse related policies and legislation and a historical approach to study the history of East Timor adopting the Portuguese language in the Constitution.

The concept of ratio legis, according to Satjipto Rahardjo, is similar to the principle of law. ${ }^{4}$ It allows us to understand the ethical direction of a statutory regulation. Thus, we can develop an effective structure based on existing regulations. Therefore, it is clear that, in building a legal order, there must be harmony between new regulations and existing regulations, both equal and higher, since the law is a unified system - one intact unit, consisting of elements that interact with one another to achieve a unified goal, according to Sudikno Mertakusumo.

To apply the philosophy of legis ratio to the use of Portuguese in the legal system, we must focus on three aspects as the main foundation of the study: ontology, epistemology and axiology. These three aspects are familiar in the direction of all science. Legal ontology discusses the nature of law, epistemology of law concerns the validation of norms and axiology is the teaching of values related to the purpose of the law. ${ }^{5}$

Language is a system: this means that it is formed by various components whose patterns are constant and can be addressed. These components have the form of sounds, each of which symbolizes a meaning or concept. Because each sound represents a concept, it can be concluded that every word in a language has a meaning. For example, rice symbolizes the concept of something that people can eat as a staple food. ${ }^{6}$ It can be concluded that among the characteristics of language are that it is arbitrary, productive, dynamic, diverse and humane. Language has four aspects: a means of communication, a cultural element, a marker of social stratification and a symbol of ethnicity and culture.

\footnotetext{
${ }^{4}$ Satjipto Rahardjo, Ilmu Hukum (Citra Aditya Bakti 2000).[4].

${ }^{5}$ Ali Z, Filsafat Hukum (Sinar Grafika 2011).[116].

${ }^{6}$ Herlina Lilis, Bahasa Dan Produk Hukum (PT Rafika Aditama 2015).[23].
} 
Language is one of the most important tools for connecting with other humans. Therefore, it is fundamental to communication. The literal meaning of language is the means used by every human being to communicate and interact with other humans. Language that appears in writing is known as written history.

Many people think that the different theories explaining the origin of language have been debated by historians so there is no clearly-expressed general agreement about the meaning of language. Even so, data from various sources suggest there are 6000 to 7000 languages in the world and they are diverse. ${ }^{7}$

Natural language is the processing of signs that can be expressed in a second medium including audio, tactile or visual simulations. Some examples of language using a second medium are Braille, graphic writing and whistling. The language used as a medium of communication is independent of its modality as an infrastructure for thinking or a means of supporting the growth of science and technology. As a basic concept, language refers to the cognitive ability to engage in a complex system of communication. It is a semiotic process that connects signs and meanings. If language is still in doubt, then there is an organised, generally agreedupon system of symbols to produce learning methods that are used as presenters when communicating. In ancient times, language became the main tool to channel values and moral beliefs, including art and religious beliefs.

According to Richard S Key, a constitution is the implementation of legal rules and the rule of law in the relationship between the community and the government. Constitutionalism creates a wide range of situations and fosters a sense of security because of the limitations set on the powers of the government.

To Carl J Friedrich, a constitution is a set of activities created by a council on behalf of the people that are subject to some restrictions in hopes of ensuring that the powers needed for governance are not misused by those who have the task of governing. ${ }^{8}$ Meriam Budihardjo claims that a constitution is a charter that states the ideals of a nation and the basis for its organisation. It contains various basic and

\footnotetext{
${ }^{7}$ Tudung Mulia Lubis, Ragam Bahasa Hukum (PT Rafika Aditama 2002).[35].

${ }^{8}$ ibid.[6].
} 
important regulations related to the distribution of power, the ideals of the country, state ideology, laws and sovereignty over political and economic issues.

In addition to constitutional rights, there is also the concept of human rights. The notion of human rights is a legal concept that states that humans have inherent rights that apply at all times, everywhere and for everyone. They are universal in principle. Human rights cannot be revoked or divided; they are interconnected and interdependent. They are usually addressed to the state - in other words, the state has the obligation to respect and protect human rights, as well as prevent and take action against violations committed by other parties.

In modern terminology, human rights can be classified into civil and political rights. Some examples of rights related to civil liberties are the right to life, the right not to be tortured and freedom of opinion. There are also economic, social and cultural rights related to access to work, education and housing. Conceptually, human rights can be based on the belief that they are naturally bestowed by one god. Meanwhile, those who believe in natural elements believe that human rights are the stewardship of values that are agreed upon by society. Others regard human rights as the representatives of the claims of those who are oppressed and claim that human rights only exist because they spark and talk about the concept. From an international standpoint, human rights can be limited or reduced in certain conditions. Restrictions usually have a legitimate purpose, which is necessary in a democratic society; they can only be enacted in an emergency that threatens the life of the nation. The outbreak of war is not sufficient for this condition. During war, international humanitarian law acts as lex specialis; even so, a number of rights cannot be infringed under any circumstances, such as the right to be free from slavery or torture.

Ancient societies did not recognise the concept of universal human rights as modern societies do. The real pioneer of the human rights discourse was the concept of natural rights, which was developed during the Enlightenment and later influenced political discourse during the French Revolution. The modern concept of human rights emerged in the second half of the twentieth century after the 
formulation of a general statement on human rights in Paris in 1948. Since then, human rights have experienced rapid development and have become a code of ethics that is accepted and enforced globally. Human rights at the international level are overseen by the Human Rights Council and UN treaty bodies, such as the Human Rights Committee and the Committee on Economic, Social and Cultural Rights. At the regional level, human rights are upheld by European, American and African human rights courts. The International Covenant on Civil and Political Rights and the International Covenant on Economic, Social and Cultural Rights have been ratified by all countries in the world.

Language has a dual role in a culture. Its cultural products also function to support the growth and development of science and technology. Without the role of the language of science, nothing can develop. The implications of the development of reasoning make language the modern infrastructure of thinking. Therefore, if we are careful in how we use language, we will also be careful in thinking because language is a reflection of the power of reason.

Accordingly, it is said that one can not possibly be an intellectual without mastering language. Intellectuals certainly need language in the thought process. Language is also a tool for the development of national culture, science and technology. The correct language is one that is in good taste and accords with the situation of the user. The use of good and correct language will produce good and correct thoughts as well. The language of a nation is a form of identity and a means of communication in modern society.

The more developed technology in our lives also has an impact on the growth and development of culture, science and technology. In this era of globalisation, East Timor must play a role in the world of free competition in the political, economic and communication fields. New concepts in the growth and development of science and technology directly enrich the authentic language of the country in which they are achieved. Thus, all cultural products, including national languages, grow and develop in accordance with the expansion of science and technology. National languages also act as infrastructure for thinking and a means of supporting 
technological growth and development. To act wisely, people must use this as a reference when a law and regulation comes into force and is binding.

This type of research is normative research ${ }^{9}$ because it studies philosophy and facts obtained from sources related to the subject matter: norms in the field of law concerning the legis ratio of the use of Portuguese in the education system in East Timor. The places of research were Canossa High School in Dili district, East Timor and the Universidade da Paz (UNPAZ).

The approaches used in this research to identify the problems with the use of Portuguese in the education system in East Timor are the statute approach, the case approach, the conceptual approach and the comparative approach.

\section{Language as a Constitutional Right of Citizens}

The East Timor Constitution regulates language in Article 13. Therefore, this section will explain the concept of constitutional rights. Constitutional rights are the norms contained in the Constitution, not only governing the organisation of state institutions but also the relations between them. Furthermore, they have led to the creation of constitutional authorities and regulate the relationship between the state and its citizens in terms of the state's authority and the people's constitutional rights. The rights of citizens are regulated in the Constitution in terms of protection from actions that can be carried out by the government, which is the holder of the people's sovereignty. Democracy does not only manifest for those who have state power; it is also visible in the people's suffrage, which is a constitutional right. It can also be seen in the rights stipulated in the Constitution. ${ }^{10}$

There are some rights mentioned in the Constitution that cannot be violated by the government in exercising state power, including citizens' rights and human rights, which are rights inherent to human dignity from birth, such as the right

\footnotetext{
${ }^{9}$ Peter Mahmud Marsuki, Penelitian Hukum (1 ${ }^{\text {st ed }}$, Kencana Prenada Media Group 2005). [93].

${ }^{10}$ A Ahsin Thohari, Hak Konstitusional Dalam Hukum Tata Negara Indonesia (PT Gelora Aksara Pratama 2016).[45].
} 
to life, the right to be treated equally and the right to obtain legal certainty and justice. These human rights actually do not depend on the state; they have always existed. ${ }^{11}$ Constitutional rights can also be seen as reciprocal with the obligations of the state mentioned in the Constitution - for example, the state's obligation to improve the welfare of its citizens and provide proper education and language that is easy to understand. Therefore, in addition to constitutional rights, which are explicitly named in the Constitution, there are also rights that can be derived from the obligations of the state and those of citizens. Rights and obligations can not be separated from one another.

There are also several rights granted by the Constitution related to the norms and goals of the state in the fields of education, economics and politics. The supremacy of the Constitution is a doctrine that rests on the recognition of the Constitution as the source of legitimacy for all policies in the legal, economic and social fields. This takes the form of constitutional review of legislative action based on the written norms of the Constitution.

All countries in the world admit that their respective Constitutions exist to promote the welfare of citizens in the fields of economy, politics and human rights. The relationship between rights and obligations is constitutional authority. As the rule of law is based on the Constitution, the limits on the exercise of state power are intended to protect the rights spelled out by the Constitution. There are actions that are prohibited. If a government violates rights that are given to citizens by the Constitution, the action is unconstitutional.

\section{Elements or Content of Constitutional Rights}

Constitutional rights are the rights of citizens guaranteed in the Constitution. Accordingly, it is unconstitutional if these rights are violated by public officials or state institutions such as presidential bodies, parliamentary institutions or

${ }^{11}$ Virgayani Fattah, 'Hak Asasi Manusia Sebagai Jus Cogens Dan Kaitannya Dengan Hak Atas Pendidikan' (2017) 2 Yuridika <https://e-journal.unair.ac.id/YDK/article/view/4775>. [3]. 
judicial institutions through either negligence or action. ${ }^{12}$ When this occurs, a court evaluates the constitutionality of the policy. Constitutional complaint is a method of protecting the rights of citizens and the last legal means by which citizens can defend themselves. It is one form of the implementation of constitutional democracy; it provides people with the ability to restore the rights guaranteed by the Constitution.

Constitutional rights are basic rights that have been adopted in the Constitution. They include human rights and citizens' rights and apply to all citizens, considering that the function of the law is to protect individuals and their basic rights. The three basic rights have become constitutional rights. In a country of law such as East Timor, the basic human rights of all citizens, which have also become constitutional rights, must be respected and fully guaranteed.

Hans Kelsen has stated that the constitutionality of legislation can only be effectively guaranteed if an organ other than the legislative body is given the task of examining whether a legal product is constitutional. This idea regarding the judicial review of the law is in line with an idea put forward by Muhammad Yamin at the trial of the investigative body in the preparation for Indonesian independence. ${ }^{13}$

\section{The Use of Portuguese in the Education System in Relation to Human Rights}

The East Timor government implemented Portuguese in the education system hastily and did not conduct a comprehensive study. Language is a determining factor for the advancement of a nation's education. Moreover, East Timor gained independence during the Fourth Industrial Revolution and has faced challenges defending itself in the midst of increasingly complex relations between nations. Therefore, the population of East Timor must prepare themselves and be proud to use their own language in daily life. It should also be used in the learning process because language is a process of thinking that allows people to formulate concepts to solve problems. ${ }^{14}$

\footnotetext{
${ }^{12}$ Damanhuri Fattah, 'Teori Keadilan Menurut John Rawls' (2013) 9 Jurnal Tapis.[31].

${ }^{13}$ Hans Kelsen, General Theory Of Law And State (1961).[157].

${ }^{14}$ Muhammad Yamin, Naskah Persiapan Undang - Undang Dasar 1945 (Yayasan Prapance 1959).[52].
} 
In addition, teachers must have mastered the language that is taught to students. If this phenomenon does not materialise, then the goal of the state to establish quality education, as outlined in the Constitution, will not be realised. If the government were responsive to the reality of Portuguese language mastery in the community, it would not force Portuguese to be used in the education system. Less than five per cent of people in East Timor understand Portuguese; they are also the older generation. Moreover, the younger generation is not enthusiastic about learning Portuguese and the application of Portuguese in the education system in East Timor has hampered the quality of education. Because teachers are crucial in the task of integrating citizens, this is an obstacle to preparing young people for the era of the Fourth Industrial Revolution. East Timor may end up lagging behind other nations because it still faces language barriers while others have entered the digital era. According to the data of this study, students want to write scientific versions of Portuguese, which is very difficult because they cannot speak Portuguese well. Lecturers are also seriously concerned that the government is applying Portuguese in the education system in East Timor.

\section{The Right to Education as a Human Right}

International human rights organisations recognise the right to education as a fundamental human right, allowing each person to develop his personality and enabling him to participate effectively in society. The fulfilment of the right to education has been stipulated in the International Covenant. Therefore, the state must fulfil the right to education. The main priority is to promote one's existence as a human being. The right to education is crucial for the fulfilment of human rights in a broad sense.

This affirmation is very important for efforts to establish quality education in East Timor. It requires collective awareness, starting with academics. More importantly, it suggests the government's responsibility to develop education that is in accordance with the culture, which is associated with the native language of the community. Coomans has said the right to education effectively gives users direct access to other rights. For Copmans, the fulfilment of the right to education 
is the fulfilment of identity and dignity. In accordance with this, Manfrek Nowak emphasises that education is a precondition for human rights.

The right to education is clearly relevant. It is addressed in Article 13 of the International Covenant on Economic, Social and Cultural Rights. Education includes various elements of both economic, social and cultural rights, as well as civil and political rights. The right to education is itself a human right and an absolutely necessary means of realising other rights. ${ }^{15}$ The establishment of an educational program must satisfy the public at large, especially in terms of the choice of language because language is important in improving the quality of education and providing reliable human resources so education is seen as a gateway to success. ${ }^{16}$

A strong connection can be seen between the right to education and the development of respect for human dignity. Education plays an important role in the empowerment of all societies because knowledge is often equated with power. ${ }^{17}$ Without education, it would be impossible for someone to access development in all aspects of life. Therefore, the importance of education is reflected in reality.

Factors Affecting the Quality of Education - Interview with 2000 Students from High School and University

\begin{tabular}{llccc}
\hline $\begin{array}{l}\text { Problems that affect the quality of } \\
\text { education }\end{array}$ & $\begin{array}{l}\text { High school students who do } \\
\text { not understand the Portuguese } \\
\text { language }\end{array}$ & $\begin{array}{l}\text { University students who } \\
\text { do not understand the } \\
\text { Portuguese language }\end{array}$ \\
\hline $\begin{array}{l}\text { School year } \\
\text { Teachers and lecturers have not }\end{array}$ & 1820 & 2019 & 2017 & 2019 \\
$\begin{array}{l}\text { mastered Portuguese } \\
\begin{array}{l}\text { Understanding Portuguese does } \\
\text { not provide economic benefits }\end{array}\end{array}$ & 1654 & 1790 & 1800 & 1744 \\
\hline
\end{tabular}

This data was gathered in September 2017 and 2019 at two schools: Canosa High School and UNPAZ University.

\footnotetext{
${ }^{15}$ General Comment On The Right to Education document, United Nations E/C.12/1999/10 77.[55]. $[55]$.

${ }^{16}$ Article 6 Of The International Covenant on Economic, Social, and Cultural Rights (1998).

${ }^{17}$ Comment on Action Plans for Basic Education United Nations Document General .E/C.12/1999/4.[33].
} 


\section{The Implications of the Portuguese Language Policy for the Quality of Education}

The right of citizens to get a quality education is stipulated in Article 59 of the Constitution of East Timor. Of course, the language used must also be understood by all citizens. In a quality education system, the main supporting factor is language. A declaration of human rights has said that education is a human right. ${ }^{18}$ This means that government policies must be in line with this declaration with regard to education. After East Timor gained independence in 2002, it ratified the International Covenant on Economic, Social and Cultural Rights, which includes education. Therefore, inevitably, the government must issue policies in the field of education that pay attention to language. To date, the implementation of Portuguese in the education system has violated the human right to access quality education.

The people of East Timor struggled for independence to be free from ignorance and poverty and strive for quality education. However, after independence, there arose differences in the use of language: a handful of people could speak Portuguese while most could not. This is a violation of the human right to obtain quality education in accordance with Article 59 of the Constitution.

It has been two decades since East Timor became independent. It should be moving in a positive direction, but it cannot be denied that the quality of education still faces many obstacles. The central problem is that teachers and lecturers do not know the Portuguese language. It is an essential responsibility of the government to respond quickly to this phenomenon. We all know that education is the foundation of the progress of a nation. On the other hand, the younger generation lacks enthusiasm to learn Portuguese. My interviews with several students revealed two problems. Learning Portuguese does not provide economic benefits; learning English, Mandarin or Korean is more promising, as it will help students work in other countries.

The application of the right to education must also not involve political, ethnic, or social interests. The school that was established by the Portuguese government

\footnotetext{
${ }^{18}$ Knut D Asplund. Suparman Marsuki dan Eko Riyadi, Hukum Hak Asasi Manusia (Pusat Studi Hak Asasi Manusia PUSHAM UII 2008).[15].
} 
in Balide is called a Portuguese school. Parents must be able to speak Portuguese before their children are admitted to the school. This shows discrimination against parents who do not speak Portuguese. We know that only a small group of parents can speak Portuguese. They are an elite group who exhibit domination in all aspects such as economic, politics and other social positions. This is also a violation of human rights.

A government policy forces private universities to use Portuguese as the medium of instruction in lectures. However, there are universities that have violated this policy because they do not want to follow the government's recommendation. Instead, they use the Tetun and Indonesian languages in the teaching and learning process because the majority of students understand and have mastered both languages. The universities have adopted these policies because they do not want to violate students' human right to access the material conveyed in lectures in accordance with Article 59 of the Constitution regarding the government's responsibility to establish quality education.

Data gathered at the UNPAZ University campus in March 2019 suggest that using Indonesian and Tetun in the teaching and learning process has been very effective. The interactions between lecturers and students were very good because the material was conveyed in Indonesian, which the students understand very well. More importantly, students looking for references for their coursework - for example, when writing scientific papers and final theses - will find it easier to locate Indonesian versions of books.

\section{Comparison of Language Use with the Philippines}

When the Philippines first became an independent country, it used Tagalog and Spanish as official languages. However, over time, the Spanish language ceased to provide benefits to the Filipino community and the government ultimately stopped forcing people to learn Spanish. However, the government does require its citizens to learn the Tagalog language because it is related to the identity of the Filipino people. It also requires its citizens to study English because it is an international 
language. Finally, Filipino people can work in any country because they can speak English and have no problems communicating with the international community.

\section{Conclusion}

Language is a constitutional right of citizens. The East Timor government applies Portuguese as the official language of the state, preventing citizens from accessing quality education, which is guaranteed in Article 59 of the Constitution. It can be formulated that the greater one's ability to speak, the more developed one's thinking. The mastery of the official language of a country is a way for people to defend their rights and obligations. In a statement on East Timorese television on 15 October 2015, President Taur Matan Ruak criticised the legal process in the courts and claimed it would be better to use Tetun so that the parties involved could understand the messages delivered by judges and lawyers directly. This would allow a suspect, defendant or convicted person to defend himself and ensure that his constitutional rights are not violated.

The use of Portuguese in the education system impedes the quality of education in East Timor and is not in line with the provisions of Article 59 of the Constitution. Those who wrote the Constitution were dominated by people who lived in Portugal, Angola and Mozambique. They could already speak Portuguese well. However, they do not know the impact of this policy on the quality of education.

The policy serves their interests and those of the Portuguese government, who want to expand the use of their language in Asia because Portuguese has entered Africa and Latin America. It also serves the interests of the older generation who once lived in Portugal, Angola, and Mozambique. It allows them to control all positions in the government by applying Portuguese and shutting out the generation who received an education when East Timor was still a province of Indonesia.

\section{Bibliography}

A Ahsin Thohari, Hak Konstitusional Dalam Hukum Tata Negara Indonesia (PT Gelora Aksara Pratama 2016). 
Ali Z, Filsafat Hukum (Sinar Grafika 2011).

Berita Nasional Timor Leste (TVTL), 'Sebaiknya Di Pengadilan Menggunakan Bahasa Tetun Supaya Para Pihak Mengerti Apa Yang Disampaikan Oleh Para Hakim' (2015).

Damanhuri Fattah, ‘Teori Keadilan Menurut John Rawls’ (2013) 9 Jurnal Tapis.

Hans Kelsen, General Theory Of Law And State (1961).

Herlina Lilis, Bahasa Dan Produk Hukum (PT Rafika Aditama 2015).

Katarina Tomasevski, Education Deniel (Zed Boos 2003).

Knut D. Asplund. Suparman Marsuki dan Eko Riyadi, Hukum Hak Asasi Manusia (Pusat Studi Hak Asasi Manusia PUSHAM UII 2008).

Komite Mengenai Hak Ekonomi Sosial dan Budaya, Komentar Umum 13 Dok PBB E/12/1999 (1999).

Muhammad Yamin, Naskah Persiapan Undang - Undang Dasar 1945 ( Yayasan Prapance 1959).

Paiseco Luis, 'Lingua Materna En Timor Leste’ [1980] Institustu Camoes.

Peter Mahmud Marsuki, Penelitian Hukum (1 ${ }^{\text {st }}$ ed, Kencana Prenada Media Group 2005).

Repository Unwira, 'Data Dari Pembngunan PBB (2006)' <https//www.repository 2019/unwira ac.id $>$ accessed 19 October 2019.

Satjipto Rahardjo, Ilmu Hukum (Citra Aditya Bakti 2000).

Tudung Mulia Lubis, Ragam Bahasa Hukum (PT Rafika Aditama 2002).

Virgayani Fattah, 'Hak Asasi Manusia Sebagai Jus Cogens Dan Kaitannya Dengan Hak Atas Pendidikan' (2017) 2 Yuridika <https://e-journal.unair.ac.id/YDK/ article/view/4775>.

HOW TO CITE: Antonino Pedro Marsal and Sukardi, 'Ratio Legis on the Right to Language in the Education System in Timor Leste' (2021) 36 Yuridika. 